\title{
NERO TETRADRACHM MINTED IN ALEXANDRIA FOUND AT PEĆINE NECROPOLIS (VIMINACIUM)
}

\begin{abstract}
During the rescue archaeological investigations of the southern necropoles at Viminacium, at one of them, Pecine, a silver Nero tetradrachm was discovered in one inhumation grave. The tetradrachm belongs to the series of the provincial mint of Alexandria (Egypt) and represents the only piece from this mint discovered so far in Viminacium.
\end{abstract}

KEYWORDS: ROMAN PROVINCIAL COINAGE, ALEXANDRIA, NERO, PEĆINE, VIMINACIUM.

Due to the required construction of TPP Kostolac 2, from the end of the 1970s until 1990, large-scale rescue archaeological investigations were conducted in the area comprising the southern necropolises of Viminacium. ${ }^{2}$ In the course of the aforementioned investigations at the necropolises of the site of Pećine, a total of 5,626 inhumation burials and 1,153 cremation burials were discovered. Of the total number of numismatic finds $(3,865),{ }^{3} 1,388$ coins were recorded in 840 inhu-

1 The study results from the project: IRS - Viminacium, Roman city and legionary camp - research of the material and non-material culture of inhabitants using the modern technologies of remote detection, geophysics, GIS, digitalisation and $3 D$ visualisation (No. 47018) - funded by The Ministry of Education, Science and Technological Development of the Republic of Serbia.

2 Зотовић 1986: 41; Golubović 2008: 15; Vojvoda, Mrđić 2015: 9; Vojvoda, Mrđić 2017: 9.

3 Coins originate from graves and from layers at the necropolis. The entire numismatic material from the aforementioned rescue investigations was inventoried during 2005 and 2006 at the National Museum in Požarevac (M. Vojvoda, D. Spasić-Đurić). It was ascertained that a number of specimens had been lost or were ruined during the process of conservation (367 coins). A similar situation, as mation burials, and 541 coins in 457 cremation burials. 1,936 coins originate from layers, which comprise the spaces between the graves and sacrificial areas formed above individual or groups of graves. Of the total number of discovered coins $(3,865), 3,497$ coins were available for processing, ranging from 32/31 BC (Marcus Antonius) to $423 \mathrm{AD}$ (Theodosius II). ${ }^{4}$ Imperial coinage comprises $84.38 \%$ and provincial $15.58 \% .^{5}$

In an inhumation grave (marked as $\mathrm{G}-4923$ ) an adult was buried without a coffin. The following grave goods were noted: next to the skull there was a perforated silver tetradrachm of Nero; some $60 \mathrm{~cm}$ from the skull, towards the south, there was

encountered during the inventorying, was also observed among specimens from the Više Grobalja necropolis based on the fieldwork documentation, 3,161 specimens were discovered, of which 2,736 were preserved ( $c f$. Vojvoda, Mrđić 2015: 10, ref. 6). On this occasion kind thanks are due to our colleague Dragana Spasić-Đurić for the material provided and her cooperation.

4 Vojvoda, Mrđić 2017: 10, Table 1.

5 Vojvoda, Mrđić 2017: 10, Graph 1. 

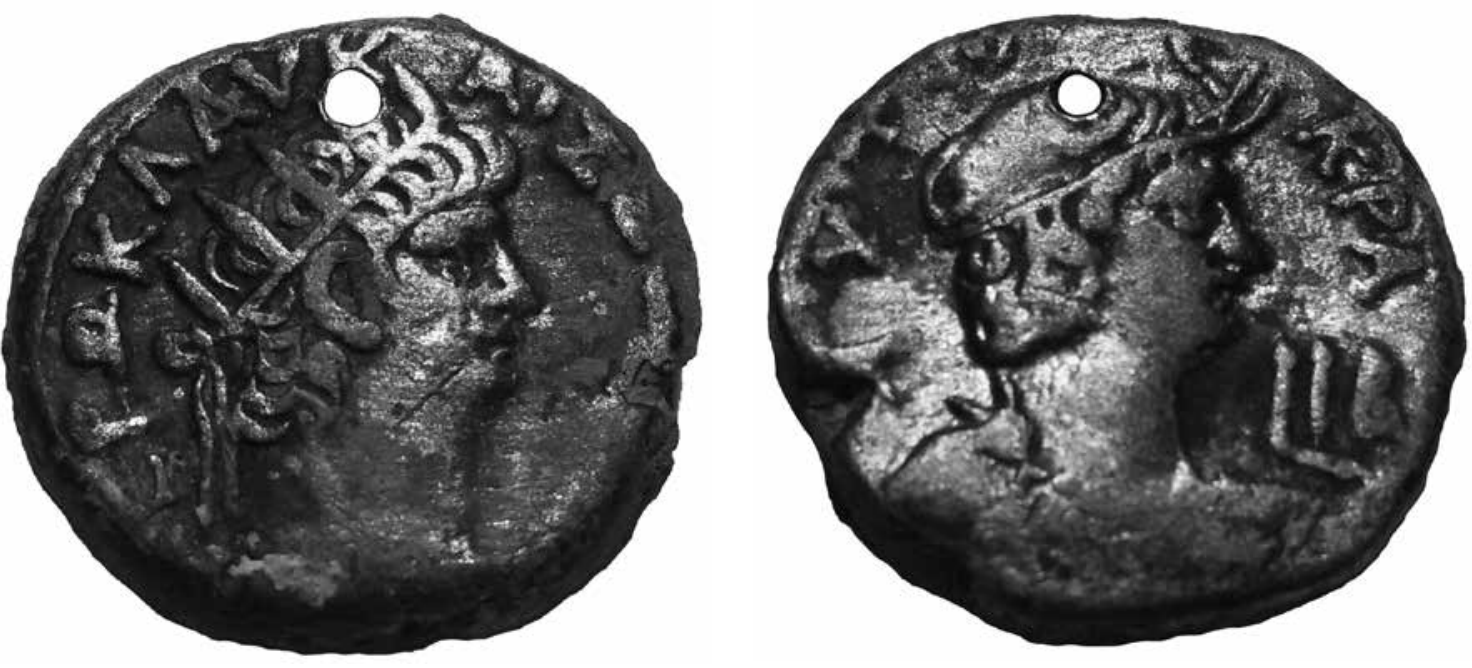

Fig. 1 obverse, reverse

a bronze key-ring; ${ }^{6}$ near the feet there was a red painted oil lamp with the stamp FLAVI7 and a bronze ring.

\section{Coin description (Fig. 1): ${ }^{8}$ \\ Mint of Alexandria (Egypt) \\ Silver tetradrachm \\ Obv. [N]EP $\Omega$ K $\Lambda$ AV K-AI $\Sigma \Sigma[\mathrm{EB}]$ [ГЕP] \\ Bust draped with aegis, right, head radiate. \\ Rv. AYTO-KPA; in field right - LIB \\ Alexandria bust draped right, with elephant skin headdress. \\ Weight 13.33 gr; Size $24.02 \mathrm{~mm}$; Axis N \\ Reference: RPC I, p. 709, no. 5289 \\ Date: 65-66 AD (year 12) \\ Inventory no. C - 11960}

The silver Nero tetradrachm dated to the year 65-66 belongs to the series of the provincial mint

6 Милановић, Мрђић 2016, 250, Table 1, no. 22; 253, ref. 12; T. I.22. According to Milanović and Mrđić key-ring (C-11961) belongs to the type II/1 and was dated widely from the $2^{\text {nd }}$ to the $4^{\text {th }}$ century.

7 The name of this craftsman (FLAVI) is connected to the middle and lower Danube provinces, specifically Pannonia, Dacia, Moesia Superior and Moesia Inferior. It is concluded that they were produced from the end of the second or at the beginning of the $3^{\text {rd }}$ century; $c f$. Korać 2018: 429430, ref. 135-146.

8 Vojvoda, Mrđić 2017: 417, cat. no. 3110. of Alexandria and represents the only piece from this mint discovered so far in Viminacium. On the obverse there is an emperor's bust with an Aegis and a radial crown, while on the reverse there is the bust of the personification of Alexandria with an elephant skin headdress. It is one of 45 perforated coins discovered at the Pećine necropolis. ${ }^{9}$

The perforation is circular, made from the obverse side, from an aesthetic point of view indicating that the obverse was meant to be seen. However, the obverse axis compared to the reverse axis measures 0 degrees, also indicating that the reverse side was meant to be seen. The perforation edges were polished on both sides and show only very small traces of perforating. ${ }^{10}$ The coin was discovered next to the skull, but independently, without other perforated objects or beads. The position of the coin find could indicate its role on a string around the neck, as an independent pendant. ${ }^{11}$

Specimens of provincial coinage at the necropolis of Pećine (total number 545) appear from the 1 st to the 3 rd century, the highest incidence

923 coins were discovered in skeletal burials, six were discovered in cremations, while 22 come from the layers of the necropolis; cf. Vojvoda 2018: 65-87.

\section{Vojvoda 2018: 68, Pl. I/2.}

11 About perforated coins from the Više Grobalja and Pećine necropolises and their role in funerary rituals, $c f$. Vojvoda 2015: 53-78; Vojvoda 2018: 65-87. 
being those of the $3 \mathrm{rd}$ century $(83.26 \%)$, followed by specimens from the 2 nd century $(7.40 \%)$ and 1 st century (3.50\%). ${ }^{12}$ Among 545 specimens, coins from 13 provinces and 27 mints were recorded and between them only one coin from the Egyptian mint of Alexandria.

It is obvious that there is a huge time span between the silver Nero tetradrachm and the oil lamp with the FLAVI stamp (around 150 years). This is not the only example of a large time span, since at the Viminacium cemeteries there were several such cases with even greater time spans between several coins discovered in the same grave. 13 The presence of coins from the Julio-Claudian dynasty in graves from the 3rd century is rare, but it is not an exception.14 A similar occurrence was noticed with some hoard-finds of coins from the Danube and the Balkan provinces. Coins of triumvir Marcus Antonius and the members of the Julio-Claudian dynasty are represented in some hoards as late as the fourth decade of the 3rd century.15 Particularly conspicuous are coin issues of divus augustus pater (minting during the reign of Tiberius), which represent common finds at the Viminacium cemeteries of Više Grobalja and Pećine. ${ }^{16}$

$125.84 \%$ belong to undetermined provincial coins from the $1^{\text {st }}$ to $3^{\text {rd }}$ century; $c f$. Vojvoda, Mrđić 2017: 16-17.

13 Vojvoda, Mrđić 2015: 28-29; Vojvoda 2018: 69.

14 Gorecki 1979: 55-56, Fig. 1; Fitz 1980: 37, Tab. a, b; Istenič 1999: 203, ref. 2; Găzdac-Alföldy, Găzdac 2009: 164 , ref. 13 .

15 Kos 1986: 74-78; Borić-Brešković, Crnobrnja 2005: 13-14; Borić-Brešković, Crnobrnja 2008: 14-15; Borić-Brešković, Arsenijević 2008: 101-103, Table 2-4; Borić-Brešković, Vojvoda 2010: 22-23, ref. 10,12-13, 3135; Table 3-6b; Borić-Brešković, Vojvoda 2011: 15-18, Table 1-3, Graph 1-2, 19, ref. 29; Borić-Brešković, Vojvoda 2012: 23-26; ref. 10, Table 1-2, Graph 1.

16 At the necropolis of Više Grobalja, a total of 37 pieces were discovered that belong to the issues of divus augustus pater: of that number, 26 were unearthed from graves while 11 come from the necropolis layers. Of the total number unearthed, six coins were perforated ( $c f$. Vojvoda 2015: 53-78). At the necropolis of Pećine, a total of 19 pieces were unearthed, 14 came from graves and five from the necropolis layers. Three of them were perforated ( $c f$. Vojvoda 2018: 69). The cult of the divine Augustus was one of the most important phenomena within ideological propaganda. It was initiated during the reign of the Julio-Claudian dynasty and later, during the Principate.
We do not know when the Nero tetradrachm from this grave was perforated, but it is possible that, for a while, it was used as a pendant (on a necklace). The fact is however, that it was kept around 150 years and then deposited into a grave. Considering all the known dating information (coin, oil lamp and key-ring) it is plausible to say that the time of the funeral was from the end of the $2^{\text {nd }}$ to the first decades of the $3^{\text {rd }}$ century.

The only piece from the Alexandria mint discovered so far in Viminacium cannot be an indicator of coin circulation between Egypt and Moesia Superior. Rather, we can attribute the appearance of this coin in one grave at the Pećine necropolis to some private reasons.

Arheologija i prirodne nauke (Archaeology and Science) is an Open Access Journal. All articles can be downloaded free of charge and used in accordance with the licence Creative Commons - Attribution-NonCommercial-NoDerivs 3.0 Serbia (https://creativecommons.org/licenses/bync-nd/3.0/rs/.

Časopis Arheologija i prirodne nauke je dostupan u režimu otvorenog pristupa. Članci objavljeni u časopisu mogu se besplatno preuzeti sa sajta i koristiti u skladu sa licencom Creative Commons - Autorstvo-Nekomercijalno-Bez prerada 3.0 Srbija (https://creativecommons.org/licenses/bync-nd/3.0/rs/.

\section{BIBLIOGRAPHY}

\section{Borić-Brešković B., Arsenijević M. 2008}

The Roman Denarii Hoard from Radalj near Drina, Numizmatičar 26-27: 93-156.

\section{Borić-Brešković B., Crnobrnja N. 2005}

A Find of Roman Denarii of the Emperors of the I - II Century, from Nemenikuće on Mt. Kosmaj, Numizmatičar 24-25: 7-94. 
Borić-Brešković B., Crnobrnja N. 2008

The First and Second Century Denarii Hoard from Ušće near Obrenovac, Numizmatičar 26-27: 9-82.

\section{Borić-Brešković B., Vojvoda M. 2010}

Roman Silver Coin Hoard from the Vicinity of Požarevac, Numizmatičar 28: 26-106.

Borić-Brešković B., Vojvoda M. 2011

A Hoard of Roman Coins from Čortanovci in Srem, Numizmatičar 29, Beograd 2011: 9-282

\section{Borić-Brešković B., Vojvoda M. 2012}

A Hoard of Roman Silver Coins from the Village of Mehovine near Šabac, Numizmatičar 30: 21113.

Fitz J. 1980

A római temetők éremanyaga é a pénzforgalom, Numizmatikai Közlöny 78-79: 23-40.

Găzdac-Alföldy Á., Găzdac C. 2009 Coins in Funerary Contexts. The Case of Brigetio, In: Ex Officina... Studia in honorem Dénes Gabler, (ed. B. Szilvia), Györ: Mursella, 161-173.

\section{Golubović S. 2008}

Grobovi u obliku bunara sa nekropola Viminacijuma, Beograd 2008: Arheološki institut.

\section{Gorecki J. 1975}

Studien zur Sitte der Münzebeigabe in römerzeitlichen Körpergräbern zwischen Rhein, Mosel und Somme, Bericht der Romisch-Germanischen Kommission 56: 179-467.

\section{Istenič J. 1999}

Petovio, zahodna grobišča II, Grobne celote iz Deželnega muzeja Joanneuma v Gradcu, Ljubljana 1999: Narodni muzej Slovenije.

Korać M. 2018

Oil-lamps from Viminacium (Moesia Superior), Belgrade 2018: Institute of Archaeology.

\section{Kos P. 1986}

The Monetary Circulation in the Southeastern Alpine Region, ca. 300 BC-AD 1000, Ljubljana 1986: Narodni muzej Slovenije.

Миловановић Б., Мрђић Н. 2016

Прстен-кључеви са Виминацијума, Glasnik SAD 32: 243-260.

(Milovanović B., Mrđić N. 2016

Prsten-ključevi sa Viminacijuma, Glasnik SAD 32: 243-260.)

\section{RPC I}

Burnett A., Amandry M., Ripollés P.P., Roman Provincial Coinage, Vol. I, London - Paris 1992: The British Museum/ Bibliotheque Nationale de Paris.

\section{Vojvoda M. 2015}

Perforated coins from graves at the Viminacium necropolis of Više grobalja, Starinar LXV: 53-78.

\section{Vojvoda M. 2018}

Perforated Coins from graves at the Viminacium necropolis of Pećine, Starinar LXVIII: 65-87.

\section{Vojvoda M,, Mrđić N. 2015}

Coin finds from the Viminacium necropolis of Više grobalja and their role in funerary ritual/Nalazi novca sa viminacijumske nekropole Više grobalja i njihova uloga u pogrebnom ritualu, Belgrade 2015: Institute of Archaeology.

\section{Vojvoda M., Mrđić N. 2017}

Coin finds from the Viminacium necropolis of Pećine and their role in funerary ritual/Nalazi novca sa viminacijumske nekropole Pećine i njihova uloga u pogrebnom ritualu, Belgrade 2017: Institute of Archaeology.

\section{Зотовић Љ. 1986}

Јужне некрополе Виминација и погребни обреди, VIMINACIVM 1, Зборник радова Народног музеја у Пожаревцу бр. 1: 41-60. (Zotović LJ. 1986 
Južne nekropole Viminacija i pogrebni obredi, $V I$ MINACIVM 1, Zbornik radova Narodnog muzeja u Požarevcu br. 1: 41-60.)

\section{Зотовић Љ., Јордовић Ч. 1990}

VIMINACIVM I, Некропола »Више гробаља«, Београд 1990: Археолошки институт, Републички завод за заштиту споменика културе Београд.

(Zotović LJ., Jordović Č. 1990

VIMINACIVM I, Nekropola »Više grobalja«, Beograd 1990: Arheološki institut, Republički zavod za zaštitu spomenika kulture Beograd.)

\section{REZIME \\ NERONOVA TETRADRAHMA KOVNICE ALEKSANDRIJA PRONAĐENA NA NEKROPOLI PEĆINE (VIMINACIJUM)}

KLJUČNE REČI: RIMSKE PROVNICIJSKE KOVNICE, ALEKSANDRIJA, NERON, PEĆINE, VIMINACIUM.

Tokom zaštitnih arheoloških istraživanja južnih nekropola Viminacijuma 1986. godine na jednoj od njih (Pećine), pronađena je perforirana srebrna tetradrahma Nerona. Pripada emisijama provincijalne kovnice Aleksandrija (Egipat) i iskovana je 65-66. godine. Predstavlja jedini do sada zabeleženi nalaz ove kovnice na Viminacijumu.
Pronađena je u okviru grobne celine (G 4923) pored lobanje pokojnika. Od ostalih nalaza u grobu: zabeleženi su i: ključ-prsten; keramički žižak sa pečatom FLAVI i bronzana alka.

$\mathrm{Na}$ aversu je bista cara sa egidom i radijalnom krunom, a na reversu bista personifikacije Aleksandrije sa slonovom kožom na glavi. Perforacija je okruglog oblika, načinjena sa strane aversa, što iz estetskih razloga upućuje da je pogledu bio izložen avers. Međutim, osa reversa u odnosu na osu aversa je na 0 stepeni, što znači da je pogledu mogao biti izložen kako avers, tako i revers, jer su ivice perforacije sa strane reversa obrađene i tek neznatno pokazuju tragove bušenja.

Jednom perforirana tetradrahma pronađena je pored lobanje, samostalno bez drugih perforiranih predmeta ili perli. Mesto nalaza može upućivati na funkciju priveska na vrvici oko vrata.

$\mathrm{Na}$ osnovu drugih nalaza iz groba (keramički žižak i ključ-prsten) i njihovog datovanja, možemo pretpostaviti da je sahrana obavljena krajem 2. ili tokom prvih dekada 3. veka. Ne znamo kada je novčić bio perforiran, ali možemo pretpostaviti da je neko vreme korišćen kao privezak oko vrata, pre nego što je položen u grob.

Jedini primerak novca iz kovnice Aleksandrija otkriven na Viminacijumu do sada, ne može biti indikator cirkulacije novca između Egipta i Gornje Mezije. Pojava ovog novca u grobu na Pećinama, pre možemo pripisati nekim privatnim razlozima. 